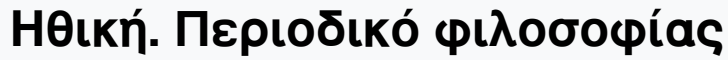

Ap. $13(2020)$

\section{НӨıкท}

ПEPIOAIKO ФINOEOФIAL

Genetic engineering and gene manipulation: the right (of future generations) to surprise

Maria K. Chorianopoulou

doi: 10.12681/ethiki.25964

13

$\triangle$ EKEMBPIO 2020

ETOE IAPYZEOS 200

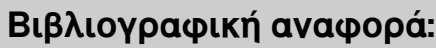

Chorianopoulou, M. K. (2021). Genetic engineering and gene manipulation: the right (of future generations) to surprise.

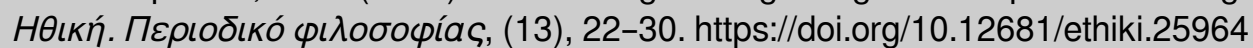




\title{
Genetic engineering and gene manipulation: The right (of future generations) to surprise ${ }^{1}$
}

\author{
Maria K. Chorianopoulou \\ National and Kapodistrian University of Athens \\ https://orcid.org/0000-0001-5720-1194
}

\begin{abstract}
Genetic engineering is currently at the forefront of biotechnological innovation and aspires to change once and for ever the way we understand and handle human nature. Especially the growth of Eugenics makes us visualise a different world, where humanity will not only dispense itself from the detrimental gene mutations that are accountable for fatal illnesses, but will also ameliorate through prenatal gene manipulation. In the first part of this paper, I will introduce the responsibility-oriented morality of Hans Jonas, who supports vividly all efforts of negative Eugenics but seems sceptical about genetic enhancement, since on the one hand we have no right to decide on behalf of our descendants on what is best for them, and on the other due to his view that the abundance of our genetic stock should not hang on parents' desires. In the second part, I will correlate these oppositions with Hannah Arendt's concept of "natality". Not only do Jonas and Habermas invoke it with applause; "natality" also discloses the very essence of birth, namely that each newborn epitomises total unpredictability and promises to renew human affairs. So, gene manipulation for enhancement purposes seems to encroach on "natality's" dominion and diminish future autonomy. Finally, I will argue that, if Arendt's conceptual frame consolidates objections to positive Eugenics, each unborn child holds a right to surprise, the content of which is not limited to an individual level but touches society and humanity.
\end{abstract}

Keywords: positive eugenics; Hans Jonas; Hannah Arendt; Jürgen Habermas; natality; enhancement; surprise

\section{Introduction}

It is an undeniable fact that the unprecedented advancement of Genetics and its various applications pose a great deal of moral dilemmas that should indispensably be taken under rigorous philosophical consideration. ${ }^{2}$ Hans Jonas was one of the first pioneering thinkers to apprehend the necessity of tackling the tough questions that arise from decoding human DNA and from the implementation of this achievement

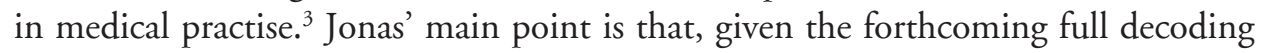
of human genome and its potential utilisation in positive and negative Eugenics, we should emergently ponder on a new and cohesive ethics, sensitive to the challenges 
that emerge from the intensified human domination of nature. ${ }^{4}$ What necessitates this ethics is the fact that no explicit distinction exists between the subject and the object of the technological experimentations. Genetic engineering has never before been exercised on human beings, but only by them. In becoming the object of his own mechanics, man obtains a terrifying degree of power, which encroaches on the future and unavoidably exerts significant influence upon the generations to come. ${ }^{5}$

\section{The necessity of a more sensitive morality}

In parallel, it is argued that present ethics is insufficient because it is becoming all the more difficult, if not unfeasible, to successfully foresee the implications of our actions both in the near and distant future; our foreknowing capabilities are incomparably limited compared with the powers we now possess. ${ }^{6}$ The more the latter is augmented, the less modern societies can predict what the consequences will be and reflect systematically on them. ${ }^{7}$ There is no doubt that now we are in need of the most precise moral weightings, capable of detecting even the subtlest consequences at long term. Also, it is noteworthy that the causal relation between present enterprises and their future imprint has dramatically changed; for the temporal distance between the time of our action and the development of its implications is so extended, that almost every prediction becomes as plausible as any other. Since the dynamic of human interference with nature and human species is rendered all the more complex, our future, the near and the distant, is increasingly affected. ${ }^{8}$ Given the above analysis, Hans Jonas wishes to launch what he emphatically calls "an ethics for the future", which will be based on the pivotal concept of responsibility. What is the key aspect of his vision? First and foremost, it is worth saying that he explicitly declares that

" 'an ethics for the future' means a contemporary ethics concerned with a future we seek to protect for our descendants from the consequences of our actions in the present". ${ }^{9}$

Additionally, the suspicion that a tone of obligation underlies the argument is finally justified:

"Without our choosing it, responsibility becomes our lot due to the sheer extent of the power we exercise daily in the service of our short-term concerns but unintentionally allow to have long-range effects. Our sense of responsibility must be commensurate with the magnitude of our power and therefore involves, like it, the entire future". ${ }^{10}$

As for the basis of his view, Jonas promotes the idea of an "ontological foundation". Obsolete as it may sound in our anti-metaphysical philosophical period, the term "ontological" refers to an element that is exclusive for the essence of a being and which can in no way be separated from it. 
If one would wish to trace man's ontological singularity, one would be driven to freedom, to man's capacity to freely and knowledgeably decide how to act by choosing between alternatives ${ }^{11}$; our species is the only one that has been awarded this ontological particularity, if I may say so. This freedom is often viewed as the very core of man's essence and, praised as his distinctive character, acquires great descriptive value in any attempt to show how human beings are. Simultaneously, Jonas does not hesitate to attribute robust normative significance to human freedom, declaring that, since we can assume responsibility thanks to our nature, we ought to do so. Thus, our duty derives from our sheer capability and no obstacle should be hold serious enough so as to undermine this solid connection. For Jonas, "the ability itself brings moral obligation with it". ${ }^{12}$

Nevertheless, there is a reasonable objection to this kind of argument. Is it legitimate, from a logical point of view, to deduce a duty from a certain reality, to ground a proposition of ought on a proposition of is? Does the way things actually are bear such an uncompromised normativity? Not at all, David Hume and Immanuel Kant would answer. ${ }^{13}$ Any natural order can not and should not determine the moral law, because the moral law is the supersensible idea of Reason ${ }^{14}$ and Kant is the most fervent champion of this view. ${ }^{15}$ Indisputably, Jonas is aware of the fact that his revolutionary attempt to formulate a responsibility ethics brings again in the spotlight the old controversy with regard to the so called naturalistic fallacy. In parallel, he consciously tries to introduce an objectively grounded ethics, which seems so strange and difficult to be accepted in the current pluralistic world. Besides, he perceives ontology in a way that leaves no room for misunderstandings: "Being, in the testimony it gives of itself, informs us not only about what it is but also about what we owe to it". ${ }^{16}$

\section{The moral imperfections of perfectionism}

Having outlined in brief the central aspects of Jonas' theory, I can now move on and show their impact on his opinion on genetic engineering. ${ }^{17}$ In principle, Jonas holds in high regard its therapeutic uses, which we tend to understand as negative Eugenics, and conceives them as a version of preventive medicine. ${ }^{18}$ For example, prenatal genetic screening tests do not impose priorities of other people on the future individual, since they just protect his right to live as a healthy person free of gene malfunctions. However, who could draw a clear line between the strictly preventive genetic engineering practices and those that aim at enhancing our gene equipment in accordance with what each generation holds as necessary enhancement? In case our genome-castle is once and for all conquered, won't the slope become too slippery to walk down? Jonas seems to cast doubt on the moral legitimacy of positive eugenics. This is because positive eugenics asks us to decide not between what is good or bad for a future person, but between what is good and what is better and, based on our assessments, to predispose him to it before his birth. ${ }^{19}$ Evil, in all its manifestations (pain, illness, death) is unanimously condemned. No one could reject its eradication without lapsing into logical contradiction, because common human sense perceives 
its existence as unwanted and worth avoiding; It could be said that the proposition which sets that evil is unwanted is analytic and not synthetic. On the other side, are we entitled to decide on behalf of the unborn child its future advantages or the virtues or future persons? in other words, who is to define that the defenceless ${ }^{20}$ embryos will become, or will be strongly predisposed to become, brilliant innovators or lively moderate persons? As Jonas puts it: 'But what is 'better' - a cool head or a warm heart, high sensitivity or robustness, a placid or a rebellious temperament, and in what proportion or distribution..." 21 Taking such crucial decisions in the absence of those immediately affected violates in advance the autonomy of the life to be born and consequently does not seem to be a morally plausible or justified option. ${ }^{22}$

On purpose of clarifying the above argument we could make use of the following thought experiment. Let's assume that in an extremely competitive social context, parents are given the opportunity to enhance their children with regard to their skills and offer them a great deal of assets useful to their establishing their status in society. Won't they take part, without their child's consent, in some kind of race for the best gene enhancement, having in mind society's demands, mainstream ideals and current tendencies within the gene market? Even though this scenario seems a remote one, the whole speculation matches perfect with Jonas' priority to the foreseeing acuteness of ethics, which must be ahead of all possible dangers and protect humanity in advance. ${ }^{23}$ Should a free gene market be created and buyers be allowed to build up the identity of their descendants, it is worryingly possible that parents will end up making uniform enhancement options, perhaps because of social pressure or fear of future failure. In this way, they could be justifiably reprimanded for making an assessment that they have no right to. ${ }^{24}$ Jonas is afraid that social stereotypes and firmly established cultural tendencies could seriously affect parental choices with regard to genetic enhancement. If such a short-sighted attitude finally prevails, it will have resulted from man's rush to attribute himself a right he is not supposed to have (more precisely the right to predetermine the unborn life) and will inevitably lead to what Jonas called "impoverishment of genetic stock" ${ }^{25}$

\section{Anticipating the unanticipated: Arendt on 'natality'}

It seems then that something of extreme importance is at stake when it comes to human reproduction. To shed light on it I will recur to the concept of "natality", which is elaborated by Hannah Arendt in her iconic book The Human Condition. ${ }^{26}$ The notion spectrum is too wide to present here, so stating its central point will suffice for my purposes. Even though Arendt makes no direct reference to bioethical questions, our attention is captured by the fact that both Jonas and Habermas use "natality" as a conceptual tool that helps them articulate their opposition to genetic enhancement. "Natality" is described as the ontological foundation of humans' capacity to act and, according to Arendt, "the fact that man is capable of action means that the unexpected can be expected from him, that he is able to perform what is infinitely improbable. And this again is possible only because each man is unique, so that with each birth something uniquely new comes into the world". ${ }^{27}$ 
"Natality", as the original background of human existence, secures that man's coming to life will signify the beginning of a course with absolutely unpredictable outcome, one that deviates from what already exists, being a potential radical turn in human life. Each birth sets in motion a sequence of initiatives and expectations, thus obtaining a messianic character; every newborn brings hope in the world and refreshes the promise that something totally new, but yet unknown, will take shape. For Arendt,

"the miracle that saves the world, the realm of human affairs, from its normal, 'natural' ruin is ultimately the tact of natality, in which the faculty of action is ontologically rooted. It is, in other words, the birth of new men and the new beginning, the action they are capable of by virtue of being born". ${ }^{28}$

Drawing from the biblical tradition, Arendt interprets the phrase "a child has been born unto us" ${ }^{29}$ as the clearest and most ideal apparition of this hope for the future of the world. Following this reasoning, Habermas annotates that every birth brings with it the possibility that "the chain of eternal recurrence" 30 could be broken and is to be seen as having an eschatological power.

Nonetheless, a burning issue arises here. What is the distinctive characteristic of "natality" that gives it its singularity and makes it so decisive in human affairs? And, once its distinctiveness is grasped, how can it be related with positive Eugenics? In commenting Arendt's argumentation, Habermas asserts that every birth chases a clear line between man's natural origin and heritage on the one hand and the human action within civilisation on the other hand. Moreover, he underlines that, thanks to this fundamental role of birth, that is of "natality", "the acting person may proceed to the self-ascriptions without which he could not perceive himself as the initiator of his actions and aspirations". ${ }^{31}$ Therefore, it seems that "natality's" significance should be searched in its pivotal naturality, which, at least until now, is not subjugated to human control and human preferences that may dictate what the equipment of the unborn life should be. ${ }^{32}$ This unhurt naturality and its unpredictable fruitfulness support our admiration for every new arrival and breathes new life to humanity's hope. The dynamic of "natality", then, lies in the fact that it introduces in the world something that is completely unconditional and that will start being known only through its gradual unfolding in time.

From this point of view, the newborn could be understood as carrying within civilisation a multidimensional cell with unknown capabilities that, to Arendt's great satisfaction, can be neither affected a priori nor known once and for all. This cell, one could add, demands patience and time, so as to unfold its content as well as to mix it with the various environmental influences. As a result, I think that positive eugenics' connection with "natality" becomes discernible: since enhancement practices would try to govern an element that was until now beyond every similar control, they would eventually cancel it, because its radical naturality would be bowed to the prescriptions of the parental design and eventually eradicated. In arrogating power over nature's 
endowment to man, civilisation would technicalise "natality", transforming it into a merely constructive procedure. Thus, the advent of the radically new (in all its forms) in human life would be disturbed, because its ontological root would have been violated; loosing this constant flux, or mystery or even miracle if you wish, of unpredictability, we would find ourselves immersed in total regularity.

Jonas' reception of "natality", apart from being outright positive, is similar to that of Habermas. ${ }^{33}$ Jonas resorts to this concept as an argument against positive Eugenics and shows what the effects will be if biotechnology infringes "natality". The latter is presented as humanity's inexhaustible source of renewal and enrichment, as a vital feedback for its spirit. Young men and women, blessed on the one hand with a (yet unknown) magnificent natural heritage, and on the other with a rich set of environmental stimuli, are persons who bring into the world the freshness of their viewpoint and promise to unfold the whole range of their capacities in a revolutionary way. In receiving natural heritage and simultaneously transforming it with the power of reason and will, youth is expected to transcend the current generation and offer new, satisfying answers for the timeless human questions. However, all these depend on our resisting the temptation of projecting on future children our personal aspirations and priorities, thus blunting "natality" and conquering one of nature's last fortresses. "Natality", then, provides constantly human life with renewed anthropological richness and reassures that humanity will never grow old both mentally and spiritually. ${ }^{34}$

\section{A new right for the future: The 'right to surprise'}

Though the philosophical incentives of Jonas, Arendt and Habermas undoubtedly differ, hereon their views seem more or less convergent; given this, I think that it would be permissible to try to transcribe these views in the language of rights, so that we see what is jeopardised here. I would argue, then, that Jonas' and Habermas' apprehension of "natality", reinforced by Arendt's rationale, seem to found what could be titled a "right to surprise". To suggest this right, I find valid reasons in one extract of Jonas himself, which is related to the question of human cloning. To be more specific, while he makes the case that each and every clone should necessarily hold the renowned "right to ignorance", Jonas presents it as "a condition for the possibility of authentic action" 35 and pronounces that morally speaking the delicate issue is "to respect the right of each human life to find its own way and be a surprise to itself". ${ }^{36}$ Even though he is not drawing systematically a picture of this right, I think that the above analysis is a solid base for its further elaboration.

In particular, as holders of the "right to surprise" one could deem each and every future person and future generations in general. With regard to its target and content, it would be a negative right, in that it would demand that parents abstain from highly binding gene options on behalf of their children, options that would significantly predetermine the development of their life. Additionally, the "right to surprise" could have two versions or, more specifically, it could be claimed in two fields. The first one would be universal, including each and every unborn child. Hereon the 
right to surprise aims at defending the inviolability of our gene constitution, so that the latter is not reduced to a means for the projection and implementation of third person wishes and priorities. The pretension is to avoid parents interfering with their offsprings' predispositions, so that they autonomously assume their "natality" and redirect it according to their values. Every human being endowed with reason is expected to formulate his life in exercising his freedom and in assimilating creatively his untouched "natality". The surpise consists to the fact that no one can prejudge the final outcome of this interaction, as well as in that the person itself is given the chance to be surprised by the self he will discover. In this respect, gene predetermination is conceived as a coercive and imposed entailment, which is radically different from the natural legacy and with which it should not be misleadingly confused.

In addition, we should not underestimate the repercussions of genetic engineering on the stability of our self-relationship; as Habermas points out, "it could, then, no longer be ruled out that alien and, in this case, genetically fixed intentions take possession, through enhancing eugenic interventions, of the life history of the programmed person" ${ }^{37}$ Since the traits originating from gene manipulation mirror third party intentions, their functional assimilation is not obvious, because they could be at odds with one's personal life plan. Besides, they represent the fate others wished for him and, should the acculturation fail, the aversion for the imposed set of characteristics could cause the phenomenon I would call "intergenerational resentment". In a few words, "intergenerational resentment" could emerge when a genetically enhanced person finds himself confined in a determinant framework others constructed for him. Indeed, it would be an omission not to mention that Michael Sandel emphasises that worries about genetic enhancement are not restricted to perfectionism or autonomy, but feature our inability to accept every child as a gift that escapes our technological might. ${ }^{38}$ Apart from reminding Arendt's touching analysis, ${ }^{39}$ he goes on to say that, morally speaking, excessive dominance over birth won't allow parents to see it as the mystery it is and will undermine their role in the $\log$ run. $^{40}$

The domain of science and research in general is the second field in which the right to surprise could be claimed. So noticeably have the technological breakthroughs changed human life and technical civilisation, that sometimes we tend to forget how crucial has been the contribution of the initial and inexplicable inspirations that kindle scientists' thought. Scientific progress is absolutely dependent on society's readiness to release human curiosity and invest on it, even if this does not always prove to be profitable. We are all acquainted with research programs that lead nowhere and with ambitious plans that collapse; at the same time it is indisputable that cultivating divergent human inclinations, that sometimes appear irrational or non-sustainable, is a presupposition for the development of human creativity, which moves towards the unknown and tries to conquer it. It is in this context that the "right to surprise" arises and indeed it could be connected to the freedom of scientific research. First of all, that right is acknowledged to the devoted researcher, who has the right (if not the duty) to expect that his scientific activity will lead to something completely new 
and unanticipated, pushing forward science and knowledge. Besides, it is the hidden anticipation of this surprise that gives him the strength to go on and attaches meaning to his lifelong efforts. Secondly, the surprise reached by the researcher belongs to science as well, since it has the "right" to await (if not to demand) the revolutionary contribution of those who devoted themselves to its progress. Third, I think that humanity as a whole is the third holder of the "right to surprise", since the quality of life at a universal level is correlated with science's advancement and scientist's responsibility to society; from this point of view, humanity's right could ground the positive duty of the researcher to surprise her. The "right to surprise", as described above, depends on our respecting "natality's" unexpectedness as well as retaining a sense of giftedness, which would also be nullified should practices of genetic selfimprovement prevail. ${ }^{41}$

\section{Conclusion}

In the light of all the above, I remain very sceptical towards positive eugenics; to me eugenics in general seems capable of eliminating the most unique core-feature of the human nature, that is, the unpredictability of its expressions; at the same time, the denaturalisation of natality seems to pose an unforeseen threat for diversity and personal inclination. Should parents be driven to uniform gene decisions, and this possibility should not be ruled out in advance, the diversity and richness of our species' gene pool would be severely compromised, and the same would apply to our future. This, of course, would have a huge impact on the status and the significance that is currently acknowledged to science. In a sense, this challenge is not just about the preservation of the species; it is also about the role science should be acknowledged and, in the long run, about its very survival.

\section{REFERENCES}

1.* I would like to express my sincere appreciation to Evangelos D. Protopapadakis, Stelios Virvidakis, Stavroula Tsinorema, Myrto Dragona - Monachou and Vana Nikolaidou - Kyrianidou for their valuable comments and remarks, as well as to thank George Politis for kindly including my contribution in the present volume.

2. Justine Burley and John Harris, Introduction to A Companion to Genethics, $\varepsilon \pi$. Justine Burley and

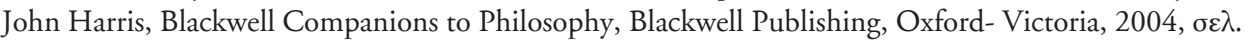
1.

3. Richard Wolin, «Ethics after Auschwitz: Hans Jonas' Notion of Responsibility in a Technological

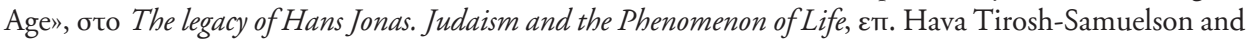

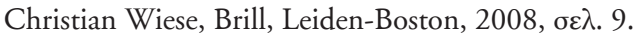

4. Hans Jonas, «Biological Engineering - A preview», бтo Hans Jonas, Philosophical Essays: From Ancient Creed to Technological Man, Prentice Hall, New Jersey, 1974, oб. 140-141.

5. Glenn McGee, The Perfect Baby: Parenthood in the New World of Cloning and Genetics, Rowman and

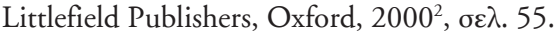

6. For the irrelevance of traditional approaches see: Julian Savulescu and Evangelos D. Protopapadakis, «Ethical Minefields and the Voice of Common Sense: A Discussion with Julian Savulescu», Conatus Journal of Philosophy 4 no. 1 (2020): oo. 125-133.

7. Richard Wolin, «Ethics after Auschwitz: Hans Jonas' Notion of Responsibility in a Technological 


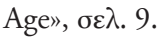

8. Hans Jonas, The Imperative of Responsibility. In Search of an Ethics for the Technological Age, The University of Chicago Press, Chicago and London, 1984, oo. 4-6.

9. Hans Jonas, «Towards an ontological grounding of an ethics for the future», oto Mortality and Morality. A search for the Good after Auschwitz, عா. Lawrence Vogel, Northwestern University Press, Illinois,

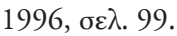

10. Hans Jonas, «Towards an ontological grounding of an ethics for the future», $\sigma \varepsilon \lambda .99$.

11. Ibid., $\sigma \varepsilon \lambda .100$

12. Ibid., $\sigma \varepsilon \lambda .101$.

13. Richard Wolin, «Ethics after Auschwitz: Hans Jonas' Notion of Responsibility in a Technological

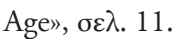

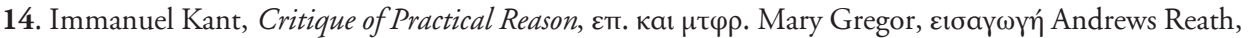

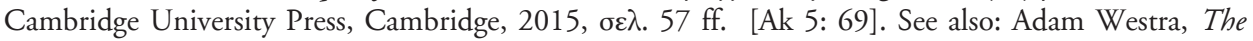
Typic in Kant's 'Critique of Practical Reason': Moral Judgment and Symbolic Representation, Walter de Gruyter, Berlin-Boston, 2016.

15. For a thorough analysis of the Kantian viewpoint see: Evangelos D. Protopapadakis, From Dawn till Dusk: Bioethical Insights into the Beginning and the End of Life, Logos Verlag, Berlin, 2019, бo. 87-88.

16. Hans Jonas, «Towards an ontological grounding of an ethics for the future», $\sigma \varepsilon \lambda .101$.

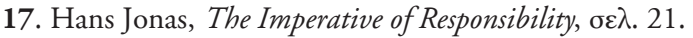

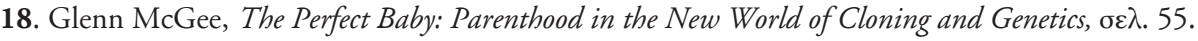

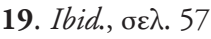

20. Ibid.

21. Hans Jonas, «Biological Engineering - A preview», $\sigma \varepsilon \lambda .152$.

22. Glenn E. McGee, Pragmatism and human genetic engineering, PhD diss., University of Vanderbilt,

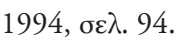

23. Frederic Ferré, «On making persons: Philosophy of Nature and Ethics», oto The legacy of Hans Jonas. Judaism and the Phenomenon of Life, $\varepsilon \pi$. Hava Tirosh-Samuelson and Christian Wiese, Brill,

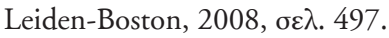

24. Glenn E. McGee, «Pragmatism and human genetic engineering», $\sigma \varepsilon \lambda .70$.

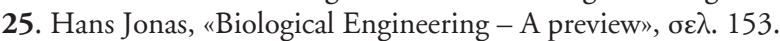

26. Margaret Canovan, «Introduction», oto The Human Condition, by Hannah Arendt, The University of Chicago Press, Chicago, $1998^{2}$, $\sigma \varepsilon \lambda$. xvii.

27. Hannah Arendt, The Human Condition, The University of Chicago Press, Chicago, 1998², $\sigma \varepsilon \lambda .178$.

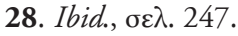

29. Old Testament, Isaiah, 9:6.

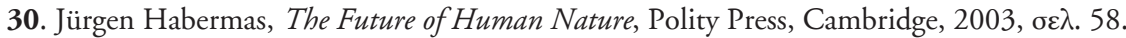

31. Ibid., $\sigma \varepsilon \lambda .59$.

32. Ibid., $\sigma \varepsilon \lambda .62$.

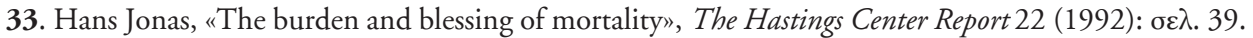

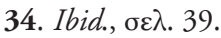

35. Bernard Prusak, "Cloning and Corporeality", oto The legacy of Hans Jonas. Judaism and the Phenom-

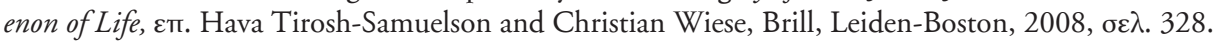

36. Hans Jonas, «Biological Engineering - A preview», $\sigma \varepsilon \lambda .163$.

37. Jürgen Habermas, The Future of Human Nature, oє $\lambda .72$.

38. Michael J. Sandel, The Case Against Perfection. Ethics in the Age of Genetic Engineering, Harvard

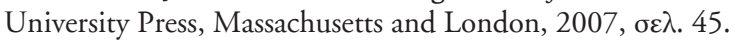

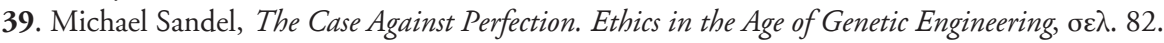

40. Ibid., or., 46-47.

41. Ibid., бб., 85-87. 